\title{
Model Development of Household Well-Being of Resource-Based Coastal Fishing Coastal Maritime In The Riau Islands Province
}

\author{
Firdaus Hamta \\ University doctoral student, \\ August 17, 1945, Surabaya, Indonesia \\ Ujianto \\ University lecturer, \\ August 17, 1945 Surabaya, Indonesia \\ Sigit Sardjono \\ University lecturer, \\ August 17, 1945 Surabaya, Indonesia
}

\begin{abstract}
This research is the development model of household welfare coastal fishing in the Riau Islands province in utilizing the potential of the maritime resources in the coastal province of Riau Islands. The population of the research was the fishing households in the coastal province of Riau Islands as much as 398 samples. Testing research of generalization done by using Least Square Estimation (GLS) model, the analysis of Structural Equation Models (SEM) with proportionate sampling method and use AIDS AMOS 21 consisting of: 5 variables, 2163 indicators and instruments. Test results showed the model fit the resulting value of the chi square 183.813, significance probability 0057, GFI, AGFI 0.9560 .934 , TLI 0.940, CFI 0.956, RMSEA 0.022, CMIN/DF 1.186 are all in the range of expected value so that the model can be accepted. The results showed that: (1) maritime coastal resource potential significant effect against the policy of the local government; (2) maritime coastal resource potential influential significantly to community empowerment; (3) the potential resources of the coastal maritime effect is not significantly to household economic behavior of coastal fishing; (4) community empowerment not significant effect against the economic behaviour of households coastal fishing; (5) the policy of local government economic behavior significantly to the influential households coastal fishing; (6) household economic behavior of coastal fishing effect significantly to public welfare_RTNP; (7) the local government policy take effect is not significantly to public welfare_RTNP; (8) community empowerment effect is not significantly to public welfare_RTNP; (9) maritime coastal resource potential effect is not significantly to public welfare_RTNP. Based on those results showed that the potential resources of the coastal maritime province Kepri can support the household well-being of fishermen on the coast, but has not yet been optimally utilized and not to increase well-being. Model development of household well-being coastal fishing can be used as an alternative in utilizing and managing maritime resource potential in the coastal province of Riau Islands province by improving several indicators to support relationship variable. The name of model of the development of household well-being coastal fishing is called ERDOGANA based management resource potential and utilization of maritime coast.
\end{abstract}

Keywords: maritime resources, policies, local governments, community empowerment, household economic behavior of coastal fishing and coastal fishing household welfare.

\section{INTRODUCTION}

The development of the maritime economy is an attempt to integrate natural resources and human resources in order to increase the production capacity of empowerment-oriented marine and land resources so as to encourage the creation of prosperity community and 
regional or national economic growth. Maritime economy in Indonesia became a serious concern because it has the potential of geographically strategic, human resources and culture. Province of Riau Islands has the potential for maritime resources because $96 \% 4.0 \%$ of sea and land. The maritime potential of up to the last line of the exclusive economic zone of Indonesia (ZEEI) in the South China Sea $\left(379,000 \mathrm{~km}^{2}\right)$. Poverty and socio-economic disparities that are distributed on the coastal communities coastal fishermen, generally require a pattern of economic development from below and in accordance with the conditions faced by coastal fishing, so the impact on changes in multidimensional structures such as increased economic and social change.

Riau Islands province coastal communities is generally poorer fishermen and life. Then it takes the regional economic development models to improve household welfare in particular against coastal fishing with managing maritime resource potential in the environment.

\section{Economic Development}

\section{LITERATURE REVIEW AND HYPOTHESIS}

Amalia (2007:1) economic development as a process that caused per capita income of a society's population increases. Per-capita income rise is a reflection of the absence of improvement in the economic well-being of the community.

Rahardjo (2012:5) is generally taken to mean economic development with economic growth but basically has the distinction, namely more extensive development than economic growth because it includes the development and modernization of institutional. Development and modernization or institution (e.g., social and economic institutions, and others) that participate and engage in the development process includes aspects of the formulation of the strategy of development policy.

\section{Community Welfare}

Suharto (2009:1) Welfare is an institution or areas of activity involving the organized activities organized by government institutions or private sector that aim to prevent, overcoming or contributed to social problem solving and improving the quality of life of individuals, groups and communities.

Social welfare indicators Statistics Indonesia the Riau Islands province (2014:21) is the population, health and nutrition, education, employment, labour force participation rates, the extent and patterns of consumption.

\section{Economic Behavior}

La Ola (2011:1) defined economics in fisheries production is the behavior of a manufacturer in the conduct of the production process to get the production of efficient, effective and high quality. Then in post harvest is a behavior in performing the production to get output that is efficient, effective and high quality (productivity).

Purwanti (2010:71) household economic behavior of fishermen: (1) production of quilon and non sea; (2) a work flow in the whole household members; (3) income of non fishing; (4) household income and expenditure on food and non food either.

\section{Government's Policy}

Sjafrizal (2014:61) Government's policy is a decision of the public in order to encourage the process of development is not only required at the national level, but also at the level of the region. Through these policies will be embodied a social condition that is expected to be able to 
push the development process towards a desirable society, both at the time and for a certain period in the future. The final goal of development policy is to be able to encourage and enhance economic growth and social welfare as a whole in accordance with the wishes and asiprasi developing in society. Limbong (2014:324) regulatory, law enforcement and institutional, budgetary politics, infrastructure development, human resources development, utilization of marine technology.

\section{Community Empowerment}

Theresia dkk (2014:28) community-based development in a simple construction which can be interpreted as referring to community needs, planned and implemented by the community with the most utilize potential resources (natural, human, institutional, socio-cultural values, etc.) and can be accessed by local people. Vitalaya (2000) in Zubaedi (2012:79) community empowerment is an attempt to build capabilities (capacity building) and empowering the existing HUMAN RESOURCES through the development of institutional and infrastructure development as well as three (3) P (mentoring, outreach and service).

\section{Potential Maritime Resources}

Limbong (2015:271) marine areas that can be developed for the nation of Indonesia, namely: (1) capture fisheries; (2) aquaculture; (3) the results of the fishery processing industry; (4) the marine biotechnology industry; (5) mining and energy; (6) marine tourism; (7) ocean freight; (8) services trade; (9) the maritime industry; (10) the small islands; (11) non-conventional resources; (12) the marine building (construction and engineering); (13) the valuable objects and cultural heritage (cultural heritage); (14) environmental services, biodiversity and conservation.

Research on the moral economy and the degree of entrepreneurship as well as household economic behavior of fishermen and the implications for the economic well-being of fishing households. Amin Indication (2015), moral economy and entrepreneurship as well as behavioral economics and significant positive effect fishermen against fishing household economic welfare. Research on local governments. Bounty (2009), local government policy in prosper fishermen requires the involvement of all parties to accelerate the growth of the fisheries subsector to create a multiplier effect for economic growth against the region so that impact to the well-being of society.

\section{Hypothesis}

1. Maritime coastal resource potential significant effect against the policy of the local government in the province of Kepri.

2. Maritime coastal resource potential influential significantly to community empowerment in the province of Kepri.

3. Maritime coastal resource potential influential economic behavior significantly to RT coastal fishing in the province of Kepri.

4. Maritime coastal resource potential significant effect against the welfare of coastal fishing in the province of Kepri.

5. The policy of local government economic behavior significantly to influential RT coastal fishing in the province of Kepri.

6. Government policy areas significant effect against the welfare of RT coastal fishing in the province of Kepri.

7. Community empowerment of influential economic behavior significantly to RT coastal fishing in the province of Kepri. 
8. Community empowerment influential significantly to public welfare_RTNP in the province of Kepri.

9. Behavioral economics RT influential coastal fishing significantly to public welfare_RTNP in the province of Kepri.

\section{CONCEPTUAL FRAMEWORK}

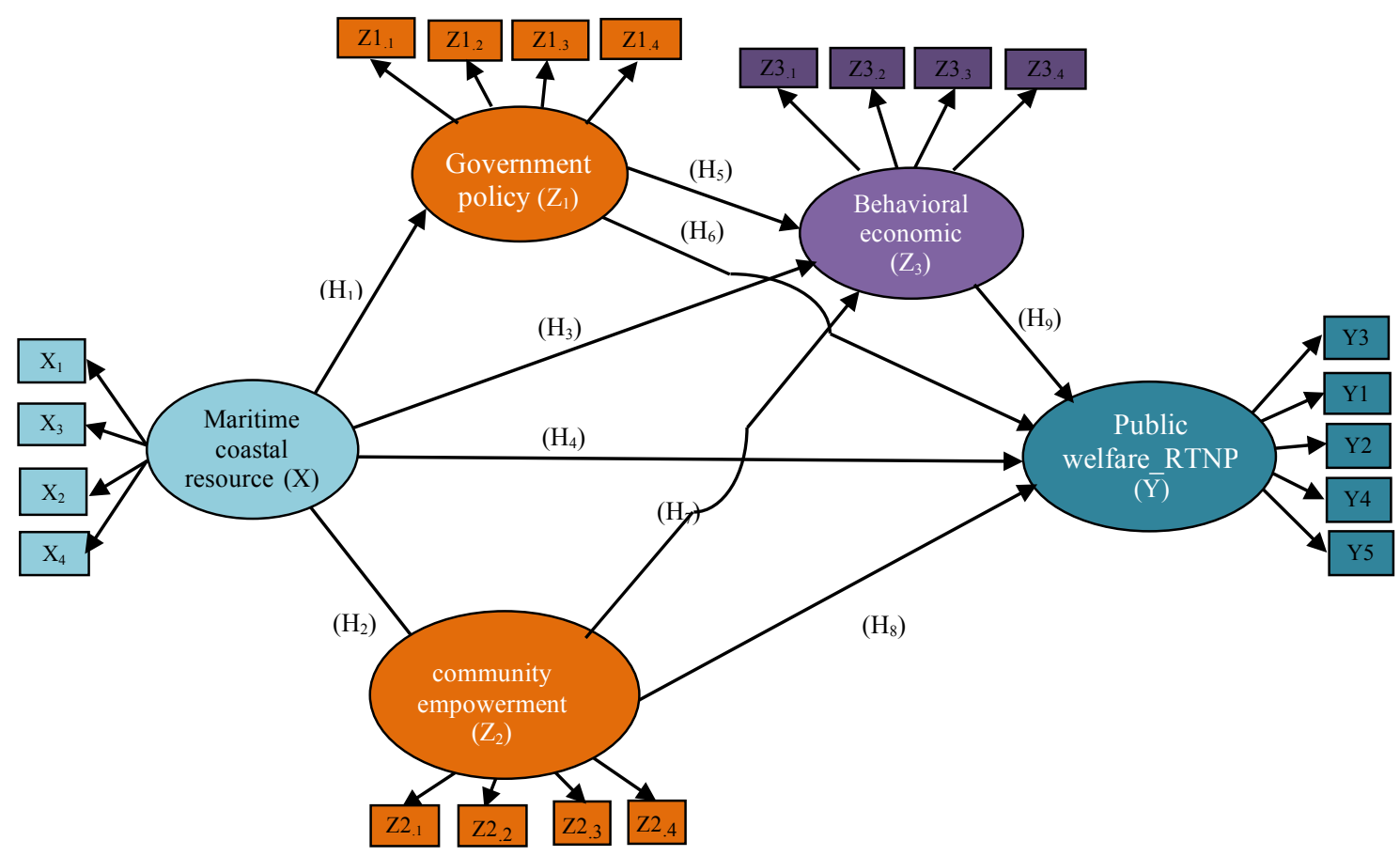

Figure 1. Conceptual framework

\section{RESEARCH METHODS}

The research of using primary data obtained from a questionnaire as a method of collecting data on the sample surveyed to find models of coastal fishermen welfare households. Total population of capture fisheries household 85,586 (RTP) or coastal fishing Households (RTNP) in the province of Riau Islands include Karimun, Batam, Tanjung Pinang, Bintan, Lingga and Natuna, Anambas. The number of samples examined 398 respondents originating from the 5 variables, 21 indicators and 63 instrument variable. These provisions correspond to provisions that use references (Hair et al., 2010, Ferdinand, 2012: 85). Data analysis in this research use analytic methods which can provide simultaneous analysis process related to the research model multi variant i.e. the analysis of Structural Equation Modeling (SEM) with Amos Version 22, Ferdinand (2010: 6).

\section{ANALYSIS AND DISCUSSION}

Test of Conformity Model (Goodness of Fit Test) testing conducted to know the condition of the fit (fit) towards improved models with the available data. Items that are used to indicate the level of significance testing to test the hypothesis. The value of the chi square 183.813 with probability of 0.057 . This shows that there is no difference between the matrix and sample matrix covarian population, so the zero hypothesis accepted (probability $\geq 0.05$ ). The value of Goodness of Fit Index Final Structural Model showing the GFI, AGFI 0.956 0.934, TLI 0.940, CFI 0.956, RMSEA 0.022, CMIN/DF 1.186. Those results showed the expected value range is set so that the model can be accepted. 
Table 1. Test result of goodness of fit index structural final model

\begin{tabular}{c|l|c|c|c}
\hline No. & Goodness Of Fit Index & Cut-Off Value & Model Test Results & Information \\
\hline 1. & chi square & & 183,813 & Good \\
2. & Significance & $\geq 0,05$ & 0,057 & Good \\
3. & probability & $\geq 0,90$ & 0,956 & Good \\
4. & GFI & $\geq 0,90$ & 0,934 & Good \\
5. & AGFI & $\geq 0,90$ & 0,940 & Good \\
6. & TLI & $\leq 0,08$ & 0,956 & Good \\
7. & CFI & $\leq 2,00$ & 0,022 & Good \\
8. & RMSEA & 1,186 & Good \\
& CMIN/DF & & & \\
\hline
\end{tabular}

Source: Prepared researcher

Table 2. Estimation of Final Parameter Model

\begin{tabular}{l|c|c|c|l}
\hline \multicolumn{1}{c|}{ Relationship Structure } & Path Koef. & C.R & P value & \multicolumn{1}{c}{ Information } \\
\hline Government policy <-- potential co mar resources & 0,296 & 3,348 & 0,000 & Significant \\
community empowerment <-- potential co mar resources & 0,288 & 2,764 & 0,006 & Significant \\
behavioral economics RT <-- Government policy & 0,051 & 0,611 & 0,541 & Not Significant \\
behavioral economics RT <-- potential co mar resources & 0,046 & 0,668 & 0,504 & Not Significant \\
behavioral economics RT <-- community empowerment & 0,131 & 2,124 & 0,034 & Significant \\
Public welfare_RTNP <-- behavioral economics RT & 0,300 & 3,225 & 0,001 & Significant \\
Public welfare_RTNP <-- Government policy & 0,009 & 0,148 & 0,883 & Not Significant \\
Public welfare_RTNP <-- community empowerment Public & $-0,140$ & $-1,729$ & 0,084 & Not Significant \\
welfare_RTNP<-- potential co mar resources & $-0,090$ & $-0,963$ & 0,335 & Not Significant \\
\hline
\end{tabular}

\section{Source: Prepared researcher}

\section{Development of Model}

Results of the analysis show the empowerment of coastal communities that were held by the public and private parties have not provided a significant impact towards behavioral economics and well-being for households of fishermen on the coast Province Of Riau Islands. Computational results Amos 21 then model developed as follows:

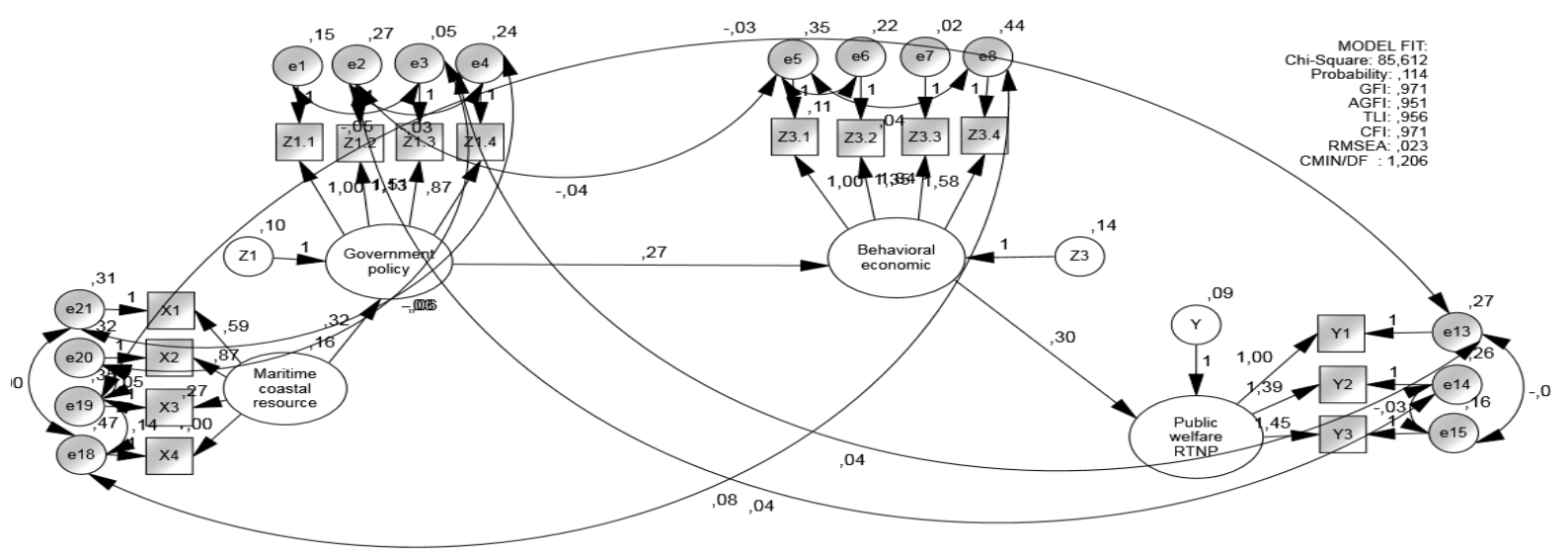

Figure 2. Structural Growth model 
Fit Model towards improved models produced values of chi square probability 85.612 with 1.14. This shows there is no difference between the matrix and sample matrix covarian population, so the zero hypothesis accepted (probability $\geq 0.05$ ). The value of Goodness of Fit Index Final Structural Model showing the GFI, AGFI 0.971 0.951, TLI 0.956, CFI 0.971, RMSEA 0.023, CMIN/DF 1.206. Those results showed the expected value range is so accepted model.

Table 3. Test Result of Goodness of Fit Index Structural Final Model

\begin{tabular}{l|l|c|c|c}
\hline No. & Goodness Of Fit Index & Cut-Off Value & Model Test Results & Information \\
\hline 1. & chi square & & 85,612 & Good \\
2. & Significance & $\geq 0,05$ & 1,14 & Good \\
3. & probability & $\geq 0,90$ & 0,971 & Good \\
4. & GFI & $\geq 0,90$ & 0,951 & Good \\
5. & AGFI & $\geq 0,90$ & 0,956 & Good \\
6. & TLI & $\leq 0,08$ & 0,971 & Good \\
7. & CFI & $\leq 2,00$ & 0,023 & Good \\
8. & RMSEA & 1,206 & Good \\
& CMIN/DF & & \\
\hline
\end{tabular}

Source: Prepared researcher

Table 4. Estimation of Final Parameter Model

\begin{tabular}{l|l|l|l|l}
\hline \multicolumn{1}{c|}{ Relationship Structure } & Path Koef. & C.R & P value & Information \\
\hline Government policy <- potential coastal & 0,371 & 2,687 & 0,007 & Significant \\
maritime resources & 0,244 & 3,408 & 0,000 & Significant \\
behavioral economics RT <- Government & 0,347 & 3,351 & 0,000 & Significant \\
policy & & & & \\
Public welfare_RTNP <- behavioral & & & & \\
economics RT & & & & \\
\hline
\end{tabular}

Source: Prepared researcher

Table 5. The Line Coefficient Between Variables

\begin{tabular}{|c|c|c|c|c|}
\hline Struktur Hubungan & $\begin{array}{l}\text { Koefisien } \\
\text { Jalur }\end{array}$ & $\begin{array}{l}\text { Nilai } \\
\text { C.R }\end{array}$ & $\begin{array}{c}\text { Probabilitas } \\
\text { (P Value })\end{array}$ & \begin{tabular}{|c} 
Keterangan \\
Sig. $\leq 0,05$ \\
\end{tabular} \\
\hline $\begin{array}{l}\text { Government policy <-- potential coastal } \\
\text { maritime resources }\end{array}$ & 0,241 & 2,501 & 0,012 & Significant \\
\hline $\begin{array}{l}\text { community empowerment <-- potential } \\
\text { coastal maritime resources }\end{array}$ & 0,131 & 1,918 & 0,055 & Not Sig. \\
\hline $\begin{array}{l}\text { behavioral economics RT <-- Government } \\
\text { policy }\end{array}$ & 0,239 & 3,095 & 0,002 & Significant \\
\hline $\begin{array}{l}\text { behavioral economics RT <-- potential coastal } \\
\text { maritime resources }\end{array}$ & 0,044 & 1,052 & 0,293 & Not Sig. \\
\hline $\begin{array}{l}\text { behavioral economics RT <-- community } \\
\text { empowerment }\end{array}$ & $-0,024$ & $-0,408$ & 0,684 & Not Sig. \\
\hline $\begin{array}{l}\text { Public welfare_RTNP <-- behavioral } \\
\text { economics RT }\end{array}$ & 0,249 & 4,390 & 0,000 & Significant \\
\hline Public welfare_RTNP <-- Government policy & 0,056 & 0,884 & 0,377 & Not Sig. \\
\hline $\begin{array}{l}\text { Public welfare_RTNP <-- community } \\
\text { empowerment }\end{array}$ & $-0,157$ & $-2,736$ & 0,006 & Significant \\
\hline $\begin{array}{l}\text { Public welfare_RTNP <-- potential coastal } \\
\text { maritime resources }\end{array}$ & $-0,006$ & $-0,171$ & 0,865 & Not Sig. \\
\hline
\end{tabular}


Table 5 above shows the path coefficients between variables, the following descriptions of research hypotheses, are as follows:

Hypothesis 1: potential coastal maritime resources effect significantly to Government policy areas Province of Kepri. Table 5 indicates that the value of the regression (standarized etimate) resulting of the $\mathrm{CR}$ value $=0.2412,502$ and $\mathrm{p}=0.012$. This means that the potential resources of the coastal maritime influential significantly to regional policy in the province Kepri. Maritime resource potential could increase local government policy amounted to $24.1 \%$ in the province of Kepri. This means the hypothesis 1 received.

Hypothesis 2: potential coastal maritime resources effect significantly to community empowerment in the province of Kepri. Table 5 showed that the value of the regression (standarized etimate) generated amounted to $0.131, \mathrm{CR}=1,918$ and $\mathrm{p}=0.055$. This means that the potential of the coastal maritime resources do not affect significantly to community empowerment of the variable in the province of Kepri. This means the hypothesis 2 resist.

Hypothesis 3: potential coastal maritime resources influential economic behavior significantly to RT coastal fishing in the province of Kepri. Table 5 showed that the value of the regression (standarized etimate) generated of $0.044, \mathrm{CR}=1,052$ and $\mathrm{p}=0,293$. This means that the potential of the coastal maritime resources do not affect economic behavior significantly to RT coastal fishing in the province of Kepri. This means Hypothesis 3 was rejected.

Hypothesis 4: potential coastal maritime resources effect significantly to the well-being of coastal fishing in the province of RT Kepri. Table 5 showed that the value of the regression (standarized etimate) generated registration-0.006, CR $=0.171$-value and $p=0,865$. This means that the potential of maritime resources has no effect significantly to the well-being of coastal fishing in the province of Kepri. This means Hypothesis 4 was rejected.

Hypothesis 5: Policy of local government economic behavior significantly to influential RT coastal fishing in the province of Kepri. Table 5 showed that the value of the regression (standarized etimate) generated of $0.239, \mathrm{CR}=3,095$ and $\mathrm{p}=0.002$. It means that the policy of local government economic behavior significantly to influential RT coastal fishing in the province of Kepri. Local government policies can improve the behavioral economics RT coastal fishing in the province of Kepri amounted to 23\%. This means the hypothesis 5 is accepted.

Hypothesis 6: Government policy areas significant effect against public welfare_RTNP in the province of Kepri. Table 5 showed that the value of the regression (standarized etimate) generated 0.056 , the value of $\mathrm{CR}=0,884$ and $\mathrm{p}=0,377$. It means that the policy of the local government do not affect significantly to public welfare_RTNP in the province of Kepri. This means the hypothesis 6 was rejected.

Hypothesis 7: community empowerment of influential economic behavior significantly to public welfare_RTNP in the province of Kepri. Table 5 showed that the value of the regression (standarized etimate) generated registration-0.024, $\mathrm{CR}=-0.408$ and $\mathrm{p}=0,684$. This means that community empowerment do not affect economic behavior significantly to RT coastal fishing in the province of Kepri. This means Hypothesis 7 was rejected.

Hypothesis 8: community empowerment effect significantly to public welfare_RTNP in the province of Kepri. Table 5 showed that the value of the regression (standarized etimate) generated registration- $0.157, \mathrm{CR}=-2.736$ and $\mathrm{p}=0.006$. This means that community 
empowerment not significant effect against public welfare_RTNP in the province of Kepri. This means the hypothesis 8 was rejected.

Hypothesis 9: behavioral economics RT influential coastal fishing significantly to public welfare_RTNP in the province of Kepri. Table 5 showed that the value of the regression (standarized etimate) generated of 0.249 and $C R=0,061$ and $p=0.000$. This means that behavioral economics RT influential coastal fishing significantly to the well-being of coastal fishing in the province of RT Kepri. Behavioral economics RT coastal fishing can increase public welfare_RTNP in the province of Kepri amounted to 24\% or 24.9\%. This means Hypothetical 9 accepted.

\section{SUMMARY}

1. Maritime coastal resource Potential significant effect against the policy of the local government in the province of Kepri. This means that the potential of the coastal maritime resources can improve significantly to Government policy areas the province of Kepri.

2. The potential of the coastal maritime resources do not affect significantly to community empowerment in the province of Kepri. This means that the potential resources of the coastal maritime could not improve significantly to the empowerment of the community significantly in the province of Kepri, but positively impact.

3. The potential of the coastal maritime resources do not affect economic behavior significantly to RT coastal fishing in the province of Kepri. It means that the coastal maritime resource potential, cannot increase significantly to behavioral economics RT coastal fishing in the province of Kepri, but positively impact.

4. The potential of the coastal maritime resources do not affect significantly to the wellbeing of coastal fishing in the province of Kepri. It means that the coastal maritime resource potential, cannot increase significantly to the well-being of coastal fishing in the province of Kepri and negative impact.

5. The policy of local government economic behavior significantly to influential RT coastal fishing in the province of Kepri. This means that the local government policy, could increase significantly to behavioral economics RT coastal fishing in the province of Kepri.

6. The Government Policies do not affect significantly to public welfare_RTNP in the province of Kepri. This means that the local government policy, no effect significantly to public welfare_RTNP in the province of Kepri, but positively impact.

7. Community empowerment do not affect economic behavior significantly to public welfare_RTNP in the province of Kepri. It means that the community empowerment, can not increase significantly to public welfare_RTNP in the province of Kepri and negative impact.

8. Community empowerment effect significantly to public welfare_RTNP in the province of Kepri. This means that community empowerment effect, significantly to public welfare_RTNP in the province Kepri, but negative impact.

9. The influence of behavioral economics RT fishermen against public welfare_RTNP in the province of Kepri. It means that, behavioral economics RT fisherman can increase significantly to public welfare_RTNP in the province of Kepri and positive impact.

\section{Regional Economic}

\section{SUGGESTIONS}

Development Authorities in the context of community welfare for RT Province Kepri, coastal fishing can be done by increasing the economic behavior of RT coastal fishing through the alignment of regional and Government policy empowerment of communities and the private 
sector to do the following things:

1. Increase of capital assistance for livestock and farming and aquaculture to reduce dependency against catch fish.

2. Increase human HR RT coastal fishing in order to manage the resource potential of skilled in coastal mainland such as farming and animal husbandry, and fishery products diversification help market access.

3. Enhance surveillance and action for the damage the environment of the coastal sea and beaches due to industrial waste, the superficiality, beach reclamation, destruction of coral reefs of the sea and mangrove forests.

4. The granting of relief equipment and supplies to catch fish in accordance with needs and expectations as well as right on target.

5. Do the construction of entrepreneurial and cooperative organizations and groups of fishermen.

6. Do the development and establishment of the cooperative fishermen engaged in basic food and supplies and equipment to support the sustainability of the fish capture food needs and activities to sea.

7. The programs of Government policy areas the province Kepri so integrated with community empowerment undertaken by public and private entities, both for coastal maritime resources utilization as well as the form of supervision and preservation of the environment the sea and shoreline (Mainland).

8. Divert support from rehab homes habitable to other programs that can drive productivity and behavioral economics RT coastal fishing.

9. Coordination with relevant agencies to provide land to farm and livestock to RT coastal fishing in Batam.

\section{Development Research}

Research the beneficial is expected in the development of research and science in particular for the welfare of RT coastal fishing and economic development of the region. the following description of the development of the research: 1 . being input or reference to do the development of research and science in particular welfare RT coastal fishing in the economic development of the region. 2. In order to develop research or veriabel variable-factors (indicators variables) are used because there are still many variables or indicators that are relevant to the factual conditions of research done on the object.

\section{BIBLIOGRAPHY}

Amalia, Lia, 2007. Economic Development. Jakarta. Graha Science. Adisasmita.

Ferdinand, A. 2010. Structural Education Modelling in research management. The first edition. Semarang: Diponegoro University.

La Ola, La Onu .2011. The Economics Of Fisheries. Kendari. Unhalu Press.

Limbong, B. 2015. Maritime Axis. Jakarta. The Library Marghareta.

Purwanti. Pudji, 2010. The Economic Model Of Small Scale Fishing Households. Malang. University Of Brawijaya.

Rahardjo, 2012. Maritime Ekonimi Development. Yogyakarta. Graha Science.

Sjafrizal, 2014. The Regional development planning in the Era of Regional Autonomy. Jakarta. The King Of Grafindo. Ferdinand, Augustus, 2010. Structural Equation Modeling in research management, first printing, Bp, Undip.

Semarang.

Suharto, Edi, 2009. Building Community Strategic Development Study Of Folk Empowering Social Welfare. Bandung; rafika Aditama.

Theresia, Aprillia, et al, 2014. Community-Based Development. Bandung: Alfabeta.

Zubaedi, 2012. The Development of The Community. Jakarta: Dawn Interpratama. 